\author{
Łukasz Ryszka \\ ORCID: 0000-0001-8267-7426
}

\title{
Wychowawczy wymiar dydaktyki Hanny Chrzanowskiej
}

\begin{abstract}
Wstęp
Każdy kontakt z drugim człowiekiem stanowi swoistą relację interpersonalną, dlatego nie można jej sprowadzić tylko do poziomu mechanicznego stosowania różnych procedur, technik czy metod. Skuteczne nauczanie również jest formą pomocy, które powinno uwzględniać kontekst aktualnej i bieżącej sytuacji. Kontekst ten mieści w sobie cechy osoby i jej subiektywny obraz sytuacji problemowej, jak też sposoby radzenia sobie $\mathrm{z}$ nią, a więc skutecznego uczenia się. Z drugiej strony, kontekst ten zawiera także cechy nauczyciela, w tym jego wiedzę o uczniu, postawę, jaką wobec niego przyjmuje, a także posiadane kompetencje i umiejętności interpersonalne. Nie można zapominać, że działanie to łączy się często ze wsparciem psychicznym, które w werbalnej i pozawerbalnej formie okazywane jest osobie ucznia. Będzie ono tym bardziej skuteczne, im lepiej dostosuje się je do konkretnej sytuacji ucznia oraz indywidualnego charakteru jego problemów.

Jan Władysław Dawid w swojej rozprawie O duszy nauczycielstwa stawia pytania o to, jakie cechy sprawiają, iż ktoś jest nauczycielem z powołania, co decyduje o wychowawczym sukcesie. Cała rozprawa opiera się na wskazaniu i opisie trzech predyspozycji nauczyciela, które są niezbędnymi warunkami wychowawczego wpływu. Są nimi: miłość dusz, skłonność do społecznego oddziaływania oraz zalety
\end{abstract}


etyczne, wśród których odnajdujemy: potrzebę doskonalenia, poczucie odpowiedzialności, obowiązkowość i moralną odwagę ${ }^{1}$.

Nauczyciel, realizując w swojej pracy założone cele i dopasowując swoje działania do różnych oczekiwań społecznych, stale musi poszukiwać nowych rozwiązań i dokonywać korekty dotychczasowych sposobów realizowanych czynności. Pomimo że nauczanie jest działaniem, w którym obowiązują reguły, nie można mówić o jakimś ich jednolitym zestawie, który gwarantowałby sukces dydaktyczny. Krzysztof Kruszewski stwierdza, że jest to raczej w dużej mierze sztuka praktyczna, która wymaga intuicji, twórczości, improwizacji i ekspresji².

Skuteczne nauczanie wymaga więc nabycia pewnego doświadczenia praktycznego, „które daje podstawę do kształcenia nauczycieli - refleksyjnych praktyków. Chodzi o to, aby nauczyciel przez analizę i ocenę własnej praktyki modyfikował i doskonalił metody nauczania. Nie ma bowiem takiej wiedzy, której aplikacje stwarzałyby podstawę rozwiązywania zdarzających się sytuacji dydaktycznych"3.

Dlatego w pracę nauczyciela musi być wpisana stała wartość ustawicznego interpretowania jej jakości, a więc systematycznego zbierania informacji na jej temat. $Z$ drugiej jednak strony takie nieustanne poszukiwanie ciągle nowych form metodologicznych i dydaktycznych grozi popadnięciem w pewien mit postępu.

Trudno również nie zgodzić się z poglądem, iż często narzucone przez ideologie lub polityczne struktury sformalizowane i zbiurokratyzowane formy pracy nauczyciela w szkole prowadzą go do pozoranctwa edukacyjnego lub czynią z wychowawcy urzędnika, a nie faktycznego partnera uczniów. Stąd też istnieje potrzeba refleksji nad kondycją współczesnego nauczyciela i jego szans na wszechstronny rozwój. Nauczyciel/pedagog mający świadomość swojego oddziaływania umie wyjść poza stereotyp i zadany szablon potrafi skierować się ku drugiemu i podjąć z nim współpracę ${ }^{4}$.

1 Por. J. Mastalski, Zarys teorii wychowania, Wydawnictwo Naukowe PAT, Kraków 2002, s. 299.

2 Por. K. Kruszewski, Sztuka nauczania. Czynności nauczyciela, Wydawnictwo Naukowe PWN, Warszawa 1991, s. 133.

3 F. Bereźnicki, Dydaktyka kształcenia ogólnego, Oficyna Wydawnicza „Impuls”, Kraków 2001, s. 259.

4 Por. B. Śliwerski, Myśleć jak pedagog, GWP, Sopot 2010, s. 79, 139. 
Szkoła potrzebuje nauczycieli jako autorytetów. Autorytet jest nam potrzebny pod względem dydaktycznym, ponieważ dzięki niemu nie musimy wszystkiego sprawdzać i weryfikować. Autorytet jest czymś koniecznym w edukacji, a zarazem nie wyklucza bliskiej relacji czy nawet przyjaźni.

Hanna Chrzanowska była pielęgniarką, która podejmowała liczne inicjatywy oraz dzieła towarzysząc chorym w ich życiu i realizując tym samym misję pomocy osobie będącej w potrzebie. Jednak jej działalność to również praca dydaktyczna wśród młodych osób pragnących nieść pomoc ludziom u schyłku życia, jak też zainicjowanie początków tzw. pielęgniarstwa domowego oraz parafialnego. Chrzanowska była aktywna również na polu twórczym, czego dowodem są jej liczne publikacje i artykuły, zachowane wystąpienia, a także poezja i proza, co pokazuje jej niezwykłą wszechstronność oraz dar skupiania się na celach, wokół których potrafiła zjednywać przychylność ludzi.

Na nagrobku Hanny Chrzanowskiej znajdującym się na Cmentarzu Rakowickim w Krakowie umieszczono napis: Hanna Chrzanowska, wierna Bogu w służbie ludziom, wybitna pielęgniarka, wychowawczyni $i$ organizatorka. Słowa te wskazują na istotne wymiary jej życia i działalności, dlatego warto pochylić się w refleksji naukowej nad postacią Chrzanowskiej jako nauczycielki i wskazać obszary związane z jej indywidualnymi zdolnościami pedagogiczno-dydaktycznymi, które niejako przekazała swoim uczennicom.

Na szczególną uwagę zasługują trzy obszary jej działalności jako nauczyciela. Pierwszy z nich dotyczy bezpośredniej pracy nad sobą i związany jest $z$ autoedukacją. Drugim jest obszar społecznego oddziaływania nauczyciela. Obszar trzeci dotyka sfery emocjonalnej powiązanej z wymiarem duchowym nauczyciela.

\section{Rys biograficzny Hanny Chrzanowskiej}

Hanna Chrzanowska urodziła się 7 października 1902 roku w Warszawie. Jej rodzicami byli Wanda Chrzanowska z domu Szlenkier, ojcem Ignacy Chrzanowski znany i ceniony naukowiec, prelegent i działacz podejmujący walkę o szkołę polską w czasie trwania rewolucji rosyjskiej i strajku szkolnego. Chrzanowski jest autorem cenionego 
podręcznika: Historia literatury niepodległej Polski, który ukazując się w 1906 roku przyniósł jej autorowi sławę i popularność ${ }^{5}$.

Atmosfera rodzinnego domu Chrzanowskich stanowiła istotny element wychowania i edukacji Hanny oraz jej starszego o 2 lata brata Bohdana. Warto wspomnieć, że dziadek Hanny, Karol Szlenkier był wielkim społecznikiem oraz mecenasem kultury, jak również inicjatorem i założycielem jednej z pierwszych prywatnych Kas Chorych, przeznaczonych dla swoich pracowników. Założył i utrzymywał Szkołę Rzemiosł w Warszawie przeznaczoną dla dzieci robotników, wprowadził tzw. akcje pracy, wręczane robotnikom po przepracowaniu u niego pięciu lat. Z kolei babcia Hanny, Maria Szlenkierowa przyczyniła się do powstania zakładu leczniczego dla dzieci robotniczych, a obydwoje wspierali też wiele innych organizacji charytatywnych. Najmłodsza z córek Szlenkierów, a ciotka Hanny, Zofia Szlenkierówna należała do pionierek świeckiego pielęgniarstwa w Polsce. Była absolwentką jednej z najbardziej znanych w Europie szkół pielęgniarskich - Szkoły Pielęgniarstwa F. Nightingale w Bordeux. To dzięki jej zaangażowaniu i odziedziczonemu majątkowi wybudowano i otwarto w 1913 roku w Warszawie Szpital im. Marii i Karola, w którym Zofia rozwijała szkolenia w zakresie pielęgniarstwa.

W 1910 roku Chrzanowscy przenieśli się do Krakowa, gdzie ojciec Hanny, Ignacy został mianowany w uznaniu dorobku naukowego, profesorem literatury polskiej na Uniwersytecie Jagiellońskim. Niewątpliwie obydwie rodziny miały znaczący wpływ na kształtowanie osobowości Hanny. Tak pisała w swoim pamiętniku: „Dzieciństwo moje - warszawskie i podwarszawskie - tak bardzo szczęśliwe, było szczęśliwe jeszcze przez to, że obie moje rodziny - ojcowska i macierzyńska - miały, każda na swój sposób, bardzo wysoki zmysł społeczny i każda realizowała go na swój sposób"6.

W 1920 roku do Krakowa przyjechali przedstawiciele Amerykańskiego Czerwonego Krzyża, a Chrzanowska uczestniczyła w kursie pielęgniarskim zorganizowanym przez Stellę Tylską z ramienia tej

5 Por. K. Kubik, Hanna Chrzanowska. Błogosławiona pielegniarka, Wydawnictwo SPES, Kraków 2018, s. 19.

6 H. Chrzanowska, Pamiętniki. Listy. Notatki, oprac. A. Rumun, M. Florkowska, Wydawnictwo Małopolskiej Okręgowej Izby Pielęgniarek i Położnych im. Hanny Chrzanowskiej, Kraków 2018, s. 6. 
organizacji. Jako ochotniczka przez dwa miesiące pełniła służbę pielęgniarską w szpitalu wojskowym, mieszczącym się w krakowskiej klinice chirurgicznej. Można powiedzieć, że było to jej pierwsze zetknięcie $\mathrm{z}$ chorym i cierpiącym. W tym samym roku Hanna zdała egzamin dojrzałości i podjęła pracę w ambulatorium Stowarzyszenia Pań Ekonomek, kierowanym przez Marię Epsteinównę, współtwórczynię i pionierkę zawodu pielęgniarskiego w Polsce.

W 1922 roku Chrzanowska rozpoczęła naukę w Warszawskiej Szkole Pielęgniarskiej kierowanej przez Hellen Bridge, po której ukończeniu w 1926 roku otrzymała tytułu pielęgniarki dyplomowanej oraz zdobyła prawo wykonywania praktyki pielęgniarskiej na terenie Rzeczpospolitej Polskiej.

Wkrótce otrzymała stypendium Fundacji Rockefellera, dzięki czemu spędziła rok w Paryżu, odbywając tam praktykę w zakresie pielęgniarstwa społecznego. Po powrocie podjęła pracę instruktorki w Krakowskiej Szkole Pielęgniarek, w której prowadziła zajęcia ze zdrowia publicznego, a także kierowała Poradnią dla Niemowląt. Po raz kolejny wyjechała na stypendium dwa lata później, tym razem do Belgii, jako uczestniczka kursu w zakresie pielęgniarstwa społecznego. Po powrocie została współredaktorką, a od czerwca 1931 roku redaktorką naczelną pierwszego polskiego zawodowego czasopisma pielęgniarskiego „Pielęgniarka Polska”.

Po wybuchu II wojny światowej Chrzanowska aktywnie włączyła się w akcję niesienia pomocy najbardziej potrzebującym. W połowie października 1939 roku zgłosiła się do pracy w Polskim Komitecie Opiekuńczym, który w 1940 roku wszedł w skład naczelnej organizacji samopomocy Polaków, Rady Głównej Opiekuńczej (RGO). W ramach tej działalności Hanna zajmowała się udzielaniem pomocy ludziom przymusowo wysiedlonym i uchodźcom oraz poszukiwaniem rodzin zastępczych dla dzieci osieroconych przez wojnę. Wykorzystywała do tego wszystkie swoje dotychczasowe doświadczenia związane z wywiadem środowiskowym.

Po zakończeniu wojny Chrzanowska rozpoczęła pracę w Uniwersyteckiej Szkole Pielęgniarskiej w Krakowie, w której została instruktorką i wicedyrektorką. Objęła kierownictwo zorganizowanego przez siebie działu pielęgniarstwa społecznego otwartego, przygotowującego uczennice do opieki nad osobami przewlekle chorymi, przebywającymi we własnych mieszkaniach. 
Na przełomie 1946 i 1947 roku uzyskała stypendium z fundacji UNRA (Organizacja Narodów Zjednoczonych do Spraw Pomocy i Odbudowy) dzięki czemu wyjechała na kilka miesięcy do Stanów Zjednoczonych, gdzie zapoznała się z pielęgniarstwem domowym. Po powrocie z USA kontynuowała swoją pracę nauczycielską w szkole pielęgniarskiej. Poza pracą w szkole krakowskiej Chrzanowska wykładała na różnych kursach dokształcających dla pielęgniarek, jak również prowadziła zajęcia $\mathrm{z}$ metodyki nauczania dla instruktorek pracujących w szkołach pielęgniarskich. Przed odejściem na emeryturę w 1958 roku, na krótko obejęła stanowisko dyrektora Szkoły Pielęgniarstwa Psychiatrycznego w podkrakowskim Kobierzynie.

Koniec pracy zawodowej nie oznaczał jednak ograniczenia jej aktywności i działań na rzecz osób chorych i potrzebujących jak i pracy dydaktycznej. W 1960 roku Chrzanowska opracowała i wydała podręcznik Pielęgniarstwo w otwartej opiece zdrowotnej, który był kilkakrotnie wznawiany.

Podczas wieloletniej pracy w szkole pielęgniarskiej Chrzanowska poznała niedostatki w zakresie pielęgniarstwa otwartego, a najpoważniejszym brakiem było pozbawienie wielu chorych stałej opieki. Współdziałając m.in. z ks. Karolem Wojtyłą zaczęła organizować pielęgniarstwo parafialne, dzięki czemu nie tylko krąg współpracowników rozszerzył się, ale swoje idee mogła przekazywać także w duszpasterstwach akademickich, prowadziła kursy pielęgniarskie w klasztorach, wygłaszała odczyty i pogadanki dla kleryków, studentów, księży i osób świeckich.

Chrzanowska dbała nie tylko o potrzeby materialne i zdrowotne podopiecznych, ale zgodnie z wyznawanymi zasadami, dążyła do zapewnienia choremu człowiekowi wsparcia wykraczającego poza zabiegi pielęgnacyjne. Dlatego wspólnie z Wojtyłą zorganizowali regularne spotkania tj. Dni Chorych, a także rekolekcje oraz comiesięczne wizyty księży w domach chorych.

W 1971 roku Chrzanowska została mianowana przez kardynała Karola Wojtyłę kierownikiem opieki pielęgniarskiej nad chorymi, w ramach parafialnego duszpasterstwa dobroczynności Archidiecezji Krakowskiej. W tym samym roku kardynał zatwierdził Regulamin Parafialnej Opieki Chorych, opracowany przez Hannę Chrzanowską.

Hanna Chrzanowska zmarła 29 kwietnia 1973 roku. 


\section{Troska o własny rozwój}

Dzisiejsza szkoła niejednokrotnie doznaje edukacyjnych niepowodzeń, których przyczyn należy szukać w zbytnim ukierunkowaniu na pragmatyzm i dydaktyczny formalizm. Wielu wskazuje, że innowacje dydaktyczne są koniecznym warunkiem nie tylko unowocześnienia procesu kształcenia, ale i zwiększenia jego efektywności. Cechą pedagogicznej innowacji jest, jak pisze Okoń, zmiana danego systemu pedagogicznego lub jego istotnej części?

Dlatego tym znacząca w procesie zmian staje się postać nauczyciela twórczego, który działa nie tylko opierając się na dydaktycznej metodyce, ale sam tworzy nowe rozwiązania i stale doskonali swój warsztat pracy. Szkoła jednak wraz z jej ustabilizowanymi programami, metodami pracy, a także wszelkiego rodzaju czynnikami strukturalnymi hamuje niekiedy te cechy twórczego nauczyciela, takie jak stałe wzbogacanie wiedzy i umiejętności, duża wiedza merytoryczna i zawodowa czy twórcza inwencja i pomysłowość ${ }^{8}$.

Hanna Chrzanowska posiadała cechy wrodzone, które pomagały jej sprostać trudnym wymaganiom. Jednak nie wystarczały one wobec ogromu zadań ${ }^{9}$. Dlatego oddając swój czas, umiejętności i siły chorym, nie zapominała o własnym rozwoju. Będąc świadoma, że bez wewnętrznego potencjału nie potrafi sprostać tak wielkim wyzwaniom, starała się rozwijać zawodowo, ale również i na innych płaszczyznach.

Chrzanowscy dbali o edukację swoich dzieci. Hanna zdała maturę w Gimnazjum Sióstr Urszulanek w Krakowie w 1920 roku. Decyzja o kontynuowaniu edukacji w Warszawskiej Szkole Pielęgniarstwa wywołała zaskoczenie, ale spotkała się z akceptacją rodziny, chociaż nie była kontynuacją linii rodowej w tym względzie $\mathrm{e}^{10}$.

7 Zob. W. Okoń, O postępie pedagogicznym, Wydawnictwo Książka i Wiedza, Warszawa 1985, s. 253.

8 Por. F. Bereźnicki, Dydaktyka kształcenia ogólnego, Oficyna Wydawnicza „Impuls”, Kraków 2001, s. 459.

9 A.E. Klich, Służyć Chrystusowi wprost - Stuga Boża Hanna Chrzanowska, „Sosnowieckie Studia Teologiczne" 2016/2017, t. 13, s. 260.

10 Warto zauważyć, iż Chrzanowska dwukrotnie podejmowała studia na Wydziale Filozoficznym UJ w 1920 roku i w 1924 roku, jednak pielęgniarstwo było dla niej wiodącym celem. Por. M. Florkowska, Radość dawania. Hanna Chrzanowska we wspomnieniach, listach, anegdotach, Wydawnictwo św. Stanisława BM, Kraków 2018, s. 291. 
W 1924 roku Chrzanowska ukończyła szkołę pielęgniarstwa i wkrótce wyjechała na stypendium Rockefellera do Francji i Belgii, gdzie pogłębiała swą wiedzę, zwłaszcza w zakresie pielęgniarstwa społecznego. Po powrocie do kraju podjęła pracę nauczycielską, jako instruktorka pielęgniarstwa społecznego w Uniwersyteckiej Szkole Pielęgniarek i Higienistek w Krakowie, a później w Warszawskiej Szkole Pielęgniarstwa. Kolejne stypendium umożliwiło jej wyjazd do Stanów Zjednoczonych (1946-1947 roku), co zaowocowało jeszcze bardziej dogłębną znajomością założeń pielęgniarstwa domowego, a przede wszystkim ich praktycznej realizacji. Jak sama wyznała: „Poza ogólnym pogłębieniem wiedzy wyniosłam stamtąd utwierdzające mnie w przyszłych walkach pewniki: że pielęgniarstwo domowe jest pracą bardzo mądrą, bardzo szeroką, że są potrzebne, tak jak w innych działach, wysokie kwalifikacje. Tamtejsze pielęgniarki domowe to kwiat pielęgniarstwa amerykańskiego"11.

Zdobyte obserwacje i doświadczenie starała się wdrożyć po powrocie do kraju. Nieustannie podnosiła swoją wiedzę i kompetencje pielęgniarskie, a postawa otwarcia na nie towarzyszyła jej w kolejnych okresach życia ${ }^{12}$.

Po latach wiele z jej uczennic wspominało Chrzanowską jako osobę, która pociągała je swoim przykładem zaangażowania, byciem oddanym sprawie, talentem i niezwykłymi umiejętnościami zawodowymi ${ }^{13}$.

Twórczy nauczyciel w pracy musi więc nieustannie dokonywać korekty dotychczasowych sposobów realizowanych przez siebie czynności, aby lepiej osiągnąć założone cele, czy też dopasowując swoje działania do różnych, często oczekiwań społecznych. Stąd w jakość jego pracy musi być oczywiście wpisana pewna stała bardziej sformalizowana część działania, jednak nie może to być jedynym i głównym kryterium podejmowanych decyzji. Staraniu o polepszanie jakości swojej pracy powinna również towarzyszyć satysfakcja, w której chodzi o znajdowanie w danej sytuacji kreatywnego potencjału i wykorzystaniu go $\mathrm{w}$ pracy z drugim człowiekiem, uczniem. Takie doświadczenie rodzi się zazwyczaj podczas pokonywania wyzwań, kiedy każdy przypadek

\footnotetext{
11 H. Chrzanowska, Pamiętniki..., s. 121.

12 Zob. K. Kubik, Hanna Chrzanowska..., s. 207.

13 Por. P. Zuchniewicz, Siostra naszego Boga. Niezwykła historia Hanny Chrzanowskiej, Wydawnictwo ZNAK, Kraków 2017, s. 136-137.
} 
działania jest traktowany indywidualnie, niebanalnie, a owa nieznana zmienność wyznacza również kierunki aktywności nauczyciela ${ }^{14}$.

W opracowanych przez Chrzanowską Zagadnieniach etycznych $w$ pielęgniarstwie domowym można odnaleźć istotne fragmenty, które dają wyobrażenie o jej profesjonalnym i twórczym podejściu do zawodu, a jednocześnie zawierają ideę przygotowania kandydatek do podejmowania pielęgniarstwa domowego. Pisała:

każda z nas, trudniąca się pielęgniarstwem domowym, czy to absolwentka szkoły pielęgniarskiej, czy to osoba przyuczona, musi być przygotowana na wszelkie niespodzianki i musi wysoko sobie cenić tą czy inną drogą zdobyte umiejętności (...). I właśnie pielęgniarstwo domowe, dalekie od szpitalnego schematu, dzięki temu właśnie - pobudza nas do wynalazczości ${ }^{15}$.

Osobisty rozwój Chrzanowskiej związany był również z jej działalnością pisarską, która w pierwszej kolejności obejmowała publikacje dotyczące fachowej problematyki pielęgniarskiej. Jej twórczość naukowa stanowi istotny wkład w całość jej pracy jako praktyka i nauczyciela-dydaktyka. W swoich artykułach starała się wyjaśniać, czym jest zawód pielęgniarski. Wskazując na jego odrębność i samodzielność przypominała jednocześnie, że jest jednym z najbardziej humanistycznych zawodów, który opiera się na zamiłowaniu do służby drugiemu człowiekowi ${ }^{16}$.

Swoją wiedzę i doświadczenie przekazywała młodym adeptkom pielęgniarstwa. W czasopiśmie „Pielęgniarka Polska” począwszy od 1937 roku ukazywały się cykliczne artykuły, które Hanna Chrzanowska opracowywała razem z Teresą Kulczyńską. Teksty zostały wydane w wersji książkowej i stały się podręcznikiem dla wielu pokoleń pielęgniarek. Jak pisze Kubik:

do ostatniej chwili swego życia Hanna podejmowała wysiłki propagujące ideę pielęgniarstwa domowego. Jeszcze na przełomie 1972-1973 roku

$\overline{14}$ Por. Ł. Ryszka, G. Godawa, Uczniowski plebiscyt na najlepszego nauczyciela w szkole jako nieformalna metoda ewaluacji wewnętrznej w opinii laureatów, [w:] J. Grzesiak (red.), Innowacje i ewaluacja w edukacji. Narzędzia pomiaru efektów kształcenia, Wydawnictwo WPA, Kalisz 2016, s. 313.

15 H. Chrzanowska, Pamiętniki..., s. 166.

16 Por. ibidem, s. 170. 
podjęła się wspólnego (...) opracowania pogadanek dla młodzieży na temat opieki nad chorymi. Miała nadzieję w ten sposób ułatwić młodym ludziom przełamywanie oporów przed spotkaniem z obłożnie chorymi ${ }^{17}$.

Postać Hanny Chrzanowskiej ukazuje cechy nauczyciela-nowatora, tj. stałe wzbogacanie wiedzy i umiejętności, dużą wiedzę merytoryczną i zawodową, twórczą inwencję i pomysłowość, a także aktywność i zaangażowanie w pracy czy również umiejętność nawiązywania kontaktów z młodzieżą oraz realizm w działaniu.

\section{Obszar społeczny}

Współcześnie istnieje mocny trend ku tendencjom mechanistyczno-przystosowawczym i pragmatycznym, w których człowiek wyrażany jest w koncepcji homo sociologicus. Wydaje się, że takim tendencjom należy przeciwstawiać koncepcję człowieka, który jest podmiotem przeobrażeń społeczno-kulturowych i społeczno-moralnych, zmieniającym twórczo rzeczywistość. Socjalizacja rozumiana jako kształtowanie człowieka społecznego i personalizacja, czyli kształtowanie człowieka jako osoby są dwiema formami wzajemnie komplementarnych i uzupełniających się procesów.

Dobrze rozumiała to Hanna Chrzanowska, która wskazywała, że ten często praktyczny wymiar edukacji przekłada się na różne pobudki postaw społecznych, czy wyboru zawodów. „Pobudki pójścia na medycynę są bardzo różne: chęć zrobienia kariery, zainteresowanie teoretyczne czy zdobycie pozycji społecznej. Jednak nie chęć służenia"18. Hanna Chrzanowska podkreślała, że istnieje wiele zawodów, w których dzielenie się z innymi swoją wiedzą, doświadczeniem czy umiejętnościami stanowi wprost o ich istocie. Nauczyciele, lekarze, czy pracownicy socjalni i wiele innych profesji są nastawieni nie tylko na bezpośredni kontakt w celu zaspokajania potrzeb materialnych swoich podopiecznych, ale przede wszystkim osoby te poświęcają swój czas na działanie dla dobra innych osób. Nie można w tym jednak pominąć socjalizującej ich roli tj. nauczyciela, który pracując nad soba, efektywnie uczy

17 K. Kubik, Hanna Chrzanowska..., s. 200.

18

Ibidem, s. 227. 
innych bycia dla innych. Od nauczycielskich poczynań czy zapatrywań, zależy jakość nauczania/uczenia, ale i wychowania.

Chrzanowska podkreślała ogromną rolę świadomości podejmowanego wyboru do służby wobec drugiego. W ten sposób przypisywała zawodowi pielęgniarki range powołania i akcentowała przez to jego godność. Do swoich uczennic mówiła, że prestiż zawodu mają zagwarantować ich wysokie kwalifikacje osobowe. Rozumienie swojej posługi jako powołania sprawia, że pielęgniarka pozostaje zawsze blisko chorego. Nie może być to niczym innym uzasadnione, jak tylko wewnętrznym przekonaniem i poczuciem obowiązku. Bliskość między pielęgniarką a chorym jest istotą pielęgniarskiego powołania i jeśli o tym się zapomina przestaje się być pielęgniarką ${ }^{19}$.

Wspominała w swoim pamiętniku: „Kiedyś na wykładach poprzedzających praktykę, któraś z uczennic spytała: Czy do naszej pracy należy sprzątanie? Odpowiedziałam: Nie, do pracy pielęgniarskiej nie należy, ale należy do zwykłych usług wykonywanych przez każdego człowiekowi potrzebującemu" ${ }^{20}$.

Współczesny nauczyciel musi być świadomy faktu, że wielogodzinne przebywanie z uczniami czyni go, nawet poza jego wolą, postacią wzorcową - tak w dobrym jaki i złym wymiarze. Szkoła nie może być tylko miejscem, które powinno być atrakcyjne dla ucznia, a nauczyciel osobą stale poszukującą takich środków dydaktycznych, które uatrakcyjnią przekaz wiedzy. Ważną powinnością obszaru społecznego nauczyciela jest oddziaływanie nie tylko na intelekt, ale i na cechy charakteru wychowanka. Chrzanowska uczyła, że w tym przypadku działania pielęgniarek, podobnie jak i innych ludzi pracujących, muszą cechować się roztropnością polegająca na dobieraniu najlepszych środków w dążeniu do określonego celu. Wynika ona z wysokiej kultury moralnej poszczególnych osób, które wypracowały konieczną wewnętrzną determinację i odwagę. $Z$ tego bierze się postawa, którą powinno być zawsze naturalne, uprzejme i życzliwe zachowanie wobec spotykanych osób bez względu na przyjęcie, jakie nas spotyka ${ }^{21}$.

W swoim pamiętniku pisała, że „na swojej drodze spotykamy jako pielęgniarki alkoholizm, nierząd, chuligaństwo - nie wolno nam się

19 Por. H. Chrzanowska, Pamiętniki..., s. 166 i 173.

20 Ibidem, s. 126.

21 Por. K. Kubik, Hanna Chrzanowska..., s. 232. 
wahać, gdy nas wzywają. Nigdy nie kierujemy się względami wyznania, wiary czy niewiary środowiska (...) Bądźmy deszczem spadającym na równi na dobrych i złych"22.

W innym miejscu wyraźnie i stanowczo podkreślała, że z powodu czyjegoś niesprawiedliwego potraktowania nie można powiedzieć: ,ja tu przychodzić nie muszę". To nie jest postawa miłości, wielkoduszności ani bezinteresowna. Przeciwnie, to jest wielkie nieporozumienie ${ }^{23}$.

Powinnością kształcącego nauczyciela jest docenienie formowania postaw przyszłych dorosłych. Poszukujący nauczyciel to taki, który uczy wychowanków twórczego myślenia, rozbudza ciekawość i zainteresowanie, rozwija samodzielność, zachęca do intelektualnego wysiłku, wdraża do innowacyjnego działania. Hannę Chrzanowską do samego końca cechowała taka postawa, którą doceniało wiele osób. Jedna z jej uczennic tak ją charakteryzowała: „Służyła radą, pomagała w pielęgnacji, wspierała w trudnych chwilach, dzieliła się doświadczeniem, w sytuacjach nagłych - zjawiała się osobiście, ciesząc się, że może zaradzić jakiejś potrzebie. Nie unikała pracy, nawet tej najprostszej i najbardziej nieprzyjemnej. Równocześnie nieustannie szukała rozwiązań"

Kompetencje i zdolności, które wymagane są od nauczycieli jako profesjonalistów w wymiarze społecznym, muszą obejmować umiejętności przełamywania granic, a także odwagę nierutynowego reagowania w sytuacjach niesprawiedliwości społecznej. Chodzi więc o pewnego rodzaju świadectwo wiary w pewne zasady, które nauczyciel powinien stosować w praktyce. Jednostronne ujęcie człowieka w kierunku koncepcji homo sociologicus, sprowadza go do istoty dokładnie odwrotnej, dopasowanej do przeznaczonej jej jedynie jakiejś funkcji społecznej ${ }^{25}$.

\section{Obszar emocjonalno-duchowy}

Współczesne przemiany cywilizacyjne niosą ze sobą szereg niepokojących zjawisk natury społecznej, które niewątpliwie dotykają sfery

\footnotetext{
22 H. Chrzanowska, Pamiętniki..., s. 194.

23 Por. ibidem, s. 198.

24 P. Zuchniewicz, Siostra naszego Boga..., s. 154.

25 Por. B. Śliwerski, Myśleć jak pedagog..., s. 53.
} 
emocjonalnej. Zmiany te i wzrastające wymagania stawiane zawodom służb społecznych spowodowały, że koszty psychologiczne, jakie ponoszą w swojej pracy nauczyciele, lekarze, pielęgniarki, pracownicy społeczni, pracownicy służb ratowniczych, policjanci i inni są coraz poważniejsze ${ }^{26}$.

Nauczyciel chcąc działać w szkole sam musi radzić sobie z różnymi negatywnymi zjawiskami, które dotykają jego pracy. Jeśli nauczycielowi brakuje poczucia własnej wartości i podmiotowości czy też niezbędnego w pokonywaniu stresu bycia asertywnym, to jest oczywiste, że wielu z nich boi się podejmowania samodzielnych i niezależnych decyzji oraz bycia elastycznym i twórczym w postępowaniu zarówno wobec uczniów jak i wobec podmiotów składających się na środowisko edukacyjne. Dotykamy w tym miejscu istotnego znaczenia, jakim dla każdego człowieka jest odczuwanie pragnienia bycia sobą i związane jest z poczuciem własnej tożsamości ${ }^{27}$.

Tożsamość staje się czymś, co powinno zostać przez jednostkę dopiero wypracowane, ale też nigdy do końca nie stanie się jej ostateczną własnością ${ }^{28}$. Jest to też pewne pragnienie nakreślenia jakiegoś własnego projektu życia, sformułowania własnego spojrzenia na otaczający świat. W ten sposób dochodzimy do istoty, którą stanowi pojęcie duchowości.

Duchowość określana jest jako „zdolność człowieka do rozumienia siebie, własnej natury, sensu życia i powołania, a wartości duchowe to najbardziej podstawowe cele i dobra, które umożliwiają rozwój człowieka w tym, co w jego życiu najważniejsze i specyficznie ludzkie"29.

Hanna Chrzanowska dzięki rodzinie, w której się wychowywała miała możliwość korzystania z szerokiego dostępu do dóbr kultury. Duży wpływ na jej rozwój i rozeznanie we współczesnej kulturze miał ojciec Hanny Ignacy Chrzanowski. Ona sama opisuje relację z nim jako przyjacielską, której nicią była forma porozumiewania się na tle

26 H. Sęk, Wypalenie zawodowe: przyczyny i zapobieganie, Wydawnictwo Naukowe PWN, Warszawa 2004, s. 7.

27 Por. B. Śliwerski, Myśleć jak pedagog..., s. 53

28 Por. J. Mastalski, Samotność globalnego nastolatka, Wydawnictwo Naukowe PAT, Kraków 2007, s. 426.

29 I. Kachocka, J. Janiuk, Przemiana duchowa Hanny Chrzanowskiej, [w:] B. Urbanek (red.), Zawód pielęgniarki na ziemiach polskich w XIX i XX wieku, Wydawnictwo Makmed, Warszawa 2008, s. 169. 
świata artystycznego, utworów literackich, którymi ojciec nasycał jej dzieciństwo ${ }^{30}$.

Istotnym elementem $\mathrm{w}$ tym rozwoju był również jej pobyt $\mathrm{w} \mathrm{Pa}-$ ryżu, do którego udała się w 1925 roku dzięki otrzymanemu stypendium. Wspomnienia piękna tego miasta pozostały w niej na całe życie. Również idea pomagania drugiemu człowiekowi była stale obecna w świadomości Hanny, wspominała, że wzrastała „w atmosferze pomocy drugim i tzw. wówczas dobroczynności jako najnaturalniejszej aurze"31. Została wychowana w duchu filantropijnej służby innym, która opierała się jednak na argumentacji pozareligijnej: „Nigdy nie słyszałam - ja, która wzrosłam w atmosferze dobroczynności i dobroci, że się ją pełni dla miłości Boga i z miłości Boga. Nigdy nie powiedziano mi, że mam być dobra z powodu Boga i dla Boga"32.

Mimo że rodzice Hanny nie troszczyli się zbytnio o jej rozwój religijny, to jednak postawy, które prezentowali z pewnością ułatwiły jej przyjęcie osobistej głębokie wiary, z której wynikało nastawienie do drugiego człowieka będącego w potrzebie. Głębokie duchowe przeżycie i rozwój jej religijności miał rozwinąć się wraz z jej wewnętrzną przemianą, która dokonała się w jej życiu w 1932 roku. Przełom ten dokonał się w tajemniczej atmosferze, a ona nigdy publicznie o tym nie opowiadała.

Religijność Chrzanowskiej rozwijała się opierając się na podstawowych formach zarówno osobistej jak i wspólnotowej modlitwy. Z czasem zaangażowała się w duchowość benedyktyńską, co zaowocowało decyzją wstąpienia do oblatek benedyktyńskich w Tyńcu.

Aktywność religijna nie odrywała jednak Chrzanowskiej od trudnych momentów codzienności. Przeciwnie, pogłębiając swoje życie wewnętrzne, nabierała właściwej oceny otaczającej ją rzeczywistości. Jak podkreśla jej współpracownik, o. Maissner ,jej religijność nie miała nic z egzaltacji, z aktorstwa. Bardzo ostro patrzała na księży, którzy byli nieprawdziwi, sztuczni, pokazywali coś, co nie odpowiadało jakiejś prawdzie wewnętrznej. Śmiała się z takich rzeczy"33.

\footnotetext{
30 Por. H. Chrzanowska, Pamiętniki..., s. 29.

31 M. Florkowska, Radość dawania..., s. 19.

32 H. Chrzanowska, Pamiętniki..., s. 28.

33 Wywiad Marzeny Florkowskiej z o. Karolem Meissnerem, [w:] M. Florkowska, Radość dawania..., s. 230.
} 
Umiejętność połączenia bogatego życia religijnego z intensywnym zaangażowaniem w działania zawodowe, a także uczestnictwa w życiu Kościoła ze zdrowym krytycyzmem wydają się charakterystyczną cechą postawy religijnej Chrzanowskiej, której ona sama się nie wstydziła, ale też nią nie epatowała. Jednak jej dialogiczne nastawienie do drugiego człowieka, umiejętność słuchania jego potrzeb, co stało się podstawą profesjonalnej diagnozy sytuacji chorego, było pokłosiem jej żywej, dialogowej relacji z Bogiem. Być może w tej zależności należy dostrzec jedno ze źródeł jej sukcesów dydaktycznych.

Bycie nauczycielką przy jednoczesnym zachowaniu postawy słuchania i uległości wobec chorych nadawało jej przekazowi szczególny wyraz i przekaz. We wspomnieniach jej uczennic można odnaleźć stwierdzenie, że Hanna Chrzanowska umiała włożyć w pracę tyle zapału i pogody, że zarażała nawet te siostry (pielęgniarki), które przyszły bez przekonania, tylko na polecenie przełożonych, a po pewnym czasie odnajdywały przy chorych radość i swoje miejsce ${ }^{34}$.

Duchowość, choć różnie definiowaną niezbywalnie cechuje aksjologiczność, transcendencja ja, teleologiczność, podmiotowość, jakościowy charakter procesów psychicznych i zarazem pośrednia nieuchwytność oraz wzrastanie wraz z wiekiem. Dlatego do właściwości osobowościowych nauczycieli, które składają się m.in. na duchowość nauczycielską, można zaliczyć wartości moralne, do których należą: prawość, wierność, poczucie odpowiedzialności oraz poszanowanie prawdy. Hanna Chrzanowska podkreślała, iż celem wychowania moralnego uczennic szkół pielęgniarskich jest wykształcenie moralnych przekonań, tak aby jednostki nawet w skomplikowanych sytuacjach mogły podejmować samodzielne decyzje moralne.

Jan Paweł II w przemówieniu do nauczycieli akademickich mówił, że:

Nauczyciel (...) nie przekazuje wiedzy tak, jakby to był przedmiot codziennego użytku i dobro konsumpcyjne, lecz przede wszystkim nawiązuje relację nacechowaną mądrością, i choć ze względu na dużą liczbę studentów nie jest możliwe osobiste spotkanie, to ona jednak staje się słowem życia. Wykładowca uczy, czyli, zgodnie z pierwotnym znaczeniem tego słowa, wnosi istotny wkład w budowanie osobowości. Ponadto wychowuje, czyli, w myśl starożytnej koncepcji sokratycznej, pomaga odkryć i rozwinąć

34 Por. ibidem, s. 189. 
zdolności i dary każdej osoby. Wykładowca w końcu formuje, według zasad humanizmu, który nie zawęża formacji do zdobycia koniecznych kompetencji zawodowych, lecz łączy je z solidną i przejrzystą wizją sensu własnego życia ${ }^{35}$.

\section{Zakończenie}

Praca z osobami o zróżnicowanych potrzebach, oczekiwaniach, jak również zasobach własnych domaga się stosownego wykształcenia oraz permanentnego uzupełniania swojej wiedzy i jej nieustannej weryfikacji. Bycie nauczycielem wymaga od niego podejmowania zróżnicowanych działań, interdyscyplinarnej wiedzy, jak też umiejętności i kompetencji. Dodatkowo, od nauczyciela oczekuje się odpowiednich predyspozycji osobowościowych, w tym właściwej postawy etycznej. W tym kontekście bycie nauczycielem jest misją, w której kategoria powołania w odniesieniu do jego pracy stanowi istotę wykonywanego zawodu. Trudno jest sobie wyobrazić skuteczne nauczanie bez poczucia misji, bez traktowania zawodu nauczyciela jako powołania.

W zawodzie nauczyciela powołanie powinno być też motywem do wyboru pracy. Wybierając zawód, człowiek może w nim widzieć realizację rozwoju swej osobowości, gdzie istotną część tego procesu powołania stanowi relacja międzyosobowa. Doświadczenie tej wartości oraz umiejętność wartościowania szczególnie w pracy z drugim człowiekiem jak i poświęcenie się dla niego samego oznacza m.in. pewną zdolność tworzenia nieszablonowych rozwiązań w zakresie działania, a zwłaszcza swoistego rodzaju pomocy niesionej dla innych.

Hanna Chrzanowska w swoim życiu szczególną uwagę poświęciła osobom chorym i cierpiącym. Z jednej strony posiadała umiejętność i pewną zdolność psychiczną w zakresie niesienia pomocy innym ludziom. $Z$ drugiej, było to rezultatem jej pogłębionego doświadczenia nad postępowaniem w różnych sytuacjach społecznych, mających często charakter wyborów moralnych. Chrzanowska posiadała tę umiejętność wartościowania, rozumianą jako zdolność człowieka do przewidywania następstw aktualnie podejmowanych działań, a w szczególności brania za nie odpowiedzialności.

35 Jan Paweł II, Przesłanie papieskie do uczestników VI Krajowego Zjazdu Włoskich Katolickich Nauczycieli Akademickich, nr 2, https://opoka.org.pl/biblioteka/W/WP/ jan_pawel_ii/przemowienia/akademickie_04102001.html (dostęp: 20.11.2019). 
Dotyczyło to również jej pracy dydaktycznej, w której kontekście mówimy o osobowości twórczej nauczyciela. Twórcza postawa Chrzanowskiej jako nauczyciela ujawniała się w jej inwencji na różnych płaszczyznach dydaktycznego działania, a szczególnie była obecna w codziennych jej relacjach z człowiekiem chorym i cierpiącym, pokazując w ten sposób jej uczennicom jak działać niestandardowo i zapobiegać rutynie oraz schematyzmowi działania.

Niewątpliwie istotne miejsce wśród wartości promowanych w pracy przez Chrzanowską zajmowała godność człowieka. Odkrycie jej w drugim człowieku wymagało od Chrzanowskiej wysiłku w poszukiwaniu prawdy o nim samym i jego egzystencji. Jednak dzięki temu mogła się ona stać nie tylko refleksyjnym teoretykiem, ale także praktykiem zdolnym do głębokiego namysłu nad otaczającąją rzeczywistością jako pielęgniarki i nauczyciela.

W ten praktyczny wymiar pracy była wpisana również inna stała wartość. Chrzanowska była wewnętrznie przekonana o powinności nieustannego starania się o polepszenie jakości swojego działania. Ten cel starała się również wprowadzić w kształcenie i wychowanie innych. Praca na rzecz drugiego, zwłaszcza w sytuacji jego choroby i cierpienia musi oczywiście opierać się na pewnych bardziej formalnych czynnościach czy procedurach działań. Jednak nie stanowiło to dla Chrzanowskiej jedynej orientacji i głównego kryterium działania. Stałe poszerzanie swojej wiedzy i doświadczenia, pomagały jej czerpać satysfakcję z pracy, a nie były jedynie formalizmem „odhaczania" kolejnego przypadku. Nie chodziło jej o panowanie nad sytuacją z powodu działania wyznaczonego procedurą. Chodziło o znajdowanie satysfakcji, kreatywnego potencjału i wykorzystywanie go w pracy z drugim człowiekiem. Taka satysfakcja rodzi się zazwyczaj w trakcie pokonywania wyzwań, kiedy każdy przypadek działania jest traktowany indywidualnie, niebanalnie, któremu trzeba podołać, a nie uczynić go jedynie zwykłą replikacją gotowych wzorców postępowania.

Wychowawczy wymiar dydaktyki Hanny Chrzanowskiej ma jeszcze jedno odniesienie. Związane jest ono z rolą autorytetu lub wzorca osobowego. Istotnie we współczesnej kulturze występuje dość często zagrożenie związane z pojawieniem się „fałszywych autorytetów", które propagują i szerzą bardziej konsumpcyjną filozofię życia niż prawdziwe postawy moralne. Hanna Chrzanowska poprzez swoje 
życie i działalność również nauczyciela i wychowawcy jawi się jako wzór godny naśladowania.

\begin{abstract}
Hanna Chrzanowska supported ill people, organized aid, and educated nursing staff. Her writings reveal her great professionalism, nursing competencies and efforts to provide support which goes beyond nursing care. Her activity had an educational dimension. Chrzanowska tried to put values into practice and was able to directly influence people who worked with her. She had to face a lot of difficult challenges. She strived to develop professionally and spiritually.
\end{abstract}

\title{
Bibliografia
}

Bereźnicki F., Dydaktyka kształcenia ogólnego, Oficyna Wydawnicza „Impuls”, Kraków 2001.

Chrzanowska H., Pamiętniki. Listy. Notatki, oprac. A. Rumun, M. Florkowska, Wydawnictwo Małopolskiej Okręgowej Izby Pielęgniarek i Położnych im. Hanny Chrzanowskiej, Kraków 2018.

Florkowska M., Radość dawania. Hanna Chrzanowska we wspomnieniach, listach, anegdotach, Wydawnictwo św. Stanisława BM, Kraków 2018.

Kachocka I., Janiuk J., Przemiana duchowa Hanny Chrzanowskiej, [w:] B. Urbanek (red.), Zawód pielęgniarki na ziemiach polskich w XIX i XX wieku, Wydawnictwo Makmed, Warszawa 2008.

Klich A.E., Służyć Chrystusowi wprost - Sługa Boża Hanna Chrzanowska, „Sosnowieckie Studia Teologiczne” 2016/2017, t. 13.

Kruszewski K., Sztuka nauczania. Czynności nauczyciela, Wydawnictwo Naukowe PWN, Warszawa 1991.

Kubik K., Hanna Chrzanowska. Błogosławiona pielęgniarka, Wydawnictwo SPES, Kraków 2018.

Mastalski J., Samotność globalnego nastolatka, Wydawnictwo Naukowe PAT, Kraków 2007.

Mastalski J., Zarys teorii wychowania, Wydawnictwo Naukowe PAT, Kraków 2002.

Okoń W., O postępie pedagogicznym, Wydawnictwo Książka i Wiedza, Warszawa 1985.

Ryszka Ł., Godawa G., Uczniowski plebiscyt na najlepszego nauczyciela $w$ szkole jako nieformalna metoda ewaluacji wewnętrznej w opinii laureatów, [w:] J. Grzesiak (red.), Innowacje i ewaluacja w edukacji. Narzędzia pomiaru efektów kształcenia, Wydawnictwo WPA, Kalisz 2016. 
Sęk H., Wypalenie zawodowe: przyczyny $i$ zapobieganie, Wydawnictwo Naukowe PWN, Warszawa 2004.

Śliwerski B., Myśleć jak pedagog, GWP, Sopot 2010.

Wywiad Marzeny Florkowskiej z o. Karolem Meissnerem, [w:] M. Florkowska, Radość dawania. Hanna Chrzanowska we wspomnieniach, listach, anegdotach, Wydawnictwo św. Stanisława BM, Kraków 2018.

Zuchniewicz P., Siostra naszego Boga. Niezwykła historia Hanny Chrzanowskiej, Wydawnictwo ZNAK, Kraków 2017.

\section{Netografia}

Jan Paweł II, Przesłanie papieskie do uczestników VI Krajowego Zjazdu Włoskich Katolickich Nauczycieli Akademickich, nr 2, https:/opoka. org.pl/biblioteka/W/WP/jan_pawel_ii/przemowienia/akademickie_04102001.html (dostęp: 20.11.2019). 